\title{
FACTORS THAT INFLUENCE THE DECISION TO OUTSOURCE MAINTENANCE IN THE PROCESSING INDUSTRY
}

\author{
D.J. Summers ${ }^{1}$ \& J.K. Visser ${ }^{1 *}$
}

\section{ARTICLE INFO}

\section{Article details}

Submitted by authors 26 Feb 2019 Accepted for publication 24 Feb 2021 Available online 28 May 2021

\section{Contact details}

* Corresponding author

krige.visser@up.ac.za

Author affiliations

1 Department of Engineering and

Technology Management,

University of Pretoria, South Africa

\section{ORCID® identifiers}

D.J. Summers

https://orcid.org/0000-0001-5328-165X

J.K. Visser

https://orcid.org/0000-0003-4334-9838

\section{DOI}

http: //dx.doi.org/10.7166/32-1-2127

\section{ABSTRACT}

The success rate of outsourcing in South Africa is fairly low. Companies that make the incorrect decision to outsource maintenance place themselves at risk of poor maintenance performance, a high operational cost of maintenance, and substantial costs to redevelop internal maintenance capabilities. The identification of the factors applicable to the decision to outsource maintenance can form the basis of a decision framework or model, and has the potential to improve the quality of decision-making in maintenance management. This paper discusses the results of a survey that was carried out to determine the main decision factors that maintenance and asset managers could use when they consider outsourcing some maintenance work. Most of the 62 respondents were from the oil and energy sector or the chemicals sector of South African industry. The main decision factors were identified as contractor experience, the availability of a suitable contractor, and the scarcity of skills or employees. The findings of this survey are useful for maintenance and asset managers to decide whether or not to outsource an activity, and to rank potential contractors.

\section{OPSOMMING}

Die sukseskoers van uitkontraktering in Suid-Afrika is taamlik laag. Organisasies wat die verkeerde besluit neem rakende die uitkontraktering van instandhouding verhoog die risiko van swak vertoning vir instandhouding, hoër bedryfskoste vir instandhouding en koste om ' $\mathrm{n}$ interne vermoë vir instandhouding te skep. Die identifisering van toepaslike faktore vir die besluit om instandhouding uit te kontrakteer kan die basis vorm van 'n raamwerk vir besluitneming. So 'n raamwerk of model het die potensiaal om die kwaliteit van besluitneming in instandhoudingsbestuur te verbeter. Hierdie artikel bespreek die resultate van 'n vraelys wat versprei is om te bepaal watter faktore die belangrikste is wanneer instandhoudings- en batebestuurders moet besluit of sekere instandhoudingswerk uitgekontrakteer moet word. Die meeste van die 62 respondente was werksaam in die olie en energie sektor of die chemiese sektor van die Suid-Afrikaanse nywerheid. Die belangrikste faktore wat geïdentifiseer is, was ondervinding van die kontrakteur, beskikbaarheid van 'n geskikte kontrakteur, en 'n tekort aan vaardighede en personeel. Die resultate van hierdie vraelys is nuttig vir instandhoudings- en batebestuurders om te besluit of ' $n$ aktiwiteit uitgekontrakteer moet word, en om potensiële kontrakteurs in 'n rangorde te plaas.

\subsection{Background}

Outsourcing, defined as the execution of an activity by an external organisation, contractor, or supplier, has been documented as being used in multiple business functions. The origin of outsourcing dates back to the 1960s, when companies adopted outsourcing to avoid the large capital investments required to run information systems (IS) internally [1]. The use of outsourcing reduced during the 1980s owing to a trend 
of vertical integration. However, numerous industries - including IS, automotive, and manufacturing showed a trend of continued outsourcing in the 1990s [2]. During this period the global outsourcing market grew from US\$136 billion in 1994 to US\$1.3 trillion in 1997 [3]. Outsourcing is now entrenched as common practice in the corporate world.

Historically, there was a trend in organisations to encourage the maintenance department to reduce costs, rather than valuing the benefits of maintenance - such as the damage that the function prevents [4]. Outsourcing was often considered as a way to reduce the cost of maintenance. The use of cost-reduction as the only motivator and deciding factor when considering whether or not to outsource is cited as a common mistake in maintenance outsourcing [5]. The impact of reducing the cost of maintenance on the bottom line of manufacturing plants is small compared with the impact of effective maintenance, which has the potential to contribute 5-10 per cent to the bottom-line profitability of a plant [5].

The success rate of outsourcing is poor globally and results in South Africa indicate that this is also the case domestically . A 2000 survey reported that only five per cent of companies achieve significant benefits from outsourcing [6]. A 2011 survey of coal mines in South Africa found that only 25 per cent of the 55 surveyed companies regarded outsourcing as a success [7]). Poor decision-making is often cited as the cause of failed outsourcing. Failure in outsourced maintenance can result in a loss of maintenance performance during the outsourcing period, and the process for organisations to rebuild the required capabilities to perform the given maintenance in-house is both costly and difficult.

\subsection{Research problem}

The success rate of outsourcing in South Africa, similar to global trends, is low (below 30 per cent). South African companies that make an incorrect decision to outsource maintenance place themselves at risk of poor maintenance performance, high operational maintenance costs, and substantial costs to redevelop internal maintenance capabilities.

There is currently limited documented research into the decision by industries in South Africa to outsource their maintenance. Addressing this research gap by determining the factors that apply to the decision to outsource maintenance in South Africa could form the basis of a decision framework or model, and has the potential to improve the quality of decision-making in maintenance management.

\subsection{Research objectives}

The main objective of this study was to identify the factors that are most important for decision-making in maintenance outsourcing in South Africa by addressing the following research questions:

- Which factors do South African organisations consider most applicable to the decision between performing maintenance internally and outsourcing their maintenance?

- Which of these factors takes priority when South African organisations make the decision between performing maintenance internally and outsourcing their maintenance?

\section{LITERATURE REVIEW}

The literature review for this study focused on maintenance management, outsourcing in general in a business enterprise, outsourcing of the maintenance function in an enterprise, and the factors that determine the decision about whether maintenance or part of the maintenance function should be outsourced.

\subsection{Maintenance management}

The Global Forum on Maintenance and Asset Management (GFMAM) [10] defines maintenance as "all of the actions necessary to retain an item in, or restore it to, a state in which it can perform its required function". The maintenance function plays a critical role in an organisation's ability to compete in terms of cost, quality, and performance (Söderberg \& Bengtsson [11], Campbell [12], Martin [13]). Effective maintenance increases equipment reliability, improves asset availability, extends equipment's useful life, and reduces the overall cost of production.

In many industries, maintenance is associated with high labour demand and the associated costs. Söderberg and Bengtsson [11] report maintenance as costing 15-40 per cent of an organisation's production costs. Hall, Knights and Daneshmend [14] report maintenance costs of 30-60 per cent of the overall operating cost for a typical mining company. Al-Turki [15] says that maintenance is about 30 per cent of the total running 
cost of modern manufacturing and construction businesses. Campbell and Reyes-Picknell [16] report maintenance costs of 20-50 per cent of operating costs in the mining industry. In view of the high cost of maintenance in mining, it is critically important that the costs of outsourcing should be a major factor in the outsourcing decision.

\subsection{Outsourcing in a business enterprise}

Beaumont and Sohal [17] define outsourcing as "having work that was formerly done inside the organisation performed by an external organisation". Numerous industries, including the automotive and manufacturing industries, embarked on outsourcing some activities and processes in the 1990s [2]. During this period, the global outsourcing market grew from US\$136 billion in 1994 to US\$1.3 trillion in 1997 [3].

Quinn [18] defined the core capabilities approach to outsourcing in an enterprise, saying that "companies are able to adapt to changes in their market by concentrating on core competencies and outsourcing the remaining activities".

Outsourcing for increased flexibility was reported primarily in IS outsourcing research. Ketler and Walstrom [1] stated that outsourcing should be considered when there is motivation to shift expenditure from a capital to an operating budget. Yang and Huang [19], in developing a model for IS outsourcing, noted that outsourcing can make consolidation or decentralisation functions more flexible, and can be an effective tool when re-engineering a function. Increased flexibility has been found to be a motivating factor for maintenance outsourcing for both operational flexibility and financial flexibility.

Ketler and Walstrom [1] also noted that an organisation's corporate structure and culture should be a factor in IS outsourcing decision-making. A stable, procedurally oriented organisational culture that is flexible enough to accept the adoption of outsourcing tends to be successful in outsourcing.

Steenkamp and Van der Lingen [20] studied outsourcing in the mining industry in South Africa. It was found that mining executed by the in-house workforce was not a core competency for the company that was investigated. A decision-making framework was also developed using the order winner / order qualifier structure, and several critical success factors were identified to manage the owner / mining contractor relationship.

\subsection{Maintenance outsourcing}

External suppliers are used for maintenance when peaks in demand for maintenance activities exceed internal capacity, the expected volume of demand is too low to justify in-house capability, and it is not cost-effective for the organisation to develop the expertise and specialised facilities to perform the maintenance activities [21].

Two parties are involved in an outsourcing relationship:

- The organisation, company, or firm requiring the services, referred to as 'the outsourcer'.

- The external organisation performing the outsourced activity, known as 'the outsourcee'. This external organisation is also referred to as a contractor, vendor, or service provider.

Quinn [18] said "the challenge in applying a core capabilities approach to maintenance outsourcing is the fact that how close maintenance is to operations varies according to industry".

The consideration of organisational behaviour is documented in multiple maintenance outsourcing studies. Kong [22] documented the impact of outsourcing culture, also referred to as the required change in leadership style, in outsourcing plant maintenance in the Singapore petrochemical industry. He also stated that outsourcing requires that facilitative leadership styles be adopted in place of the authoritarian leadership styles that are typically used to manage in-house maintenance. Hattingh and Govender [23], in a study of the South African mining industry, defined these changes in the organisation as a new set of skills and expertise in planning and managing the external function for outsourcing to be successful.

Tsang [24] refined the definitions of strategic relevance and competitiveness to be of greater relevance to maintenance outsourcing. Venkatesan [25] was one of the early researchers into the strategic aspects of outsourcing with a specific focus on manufacturing. He categorised products as commodity, strategic, or non-strategic, and suggested that outsourcing should only be considered for commodity and non-strategic products. He also suggested that companies only consider outsourcing strategic product manufacturing if the costs to develop internal capabilities to match those of the suppliers were not justifiable. 
Dunn [26] analysed strategic importance by considering maintenance as strategically important if cost is a driving factor and maintenance forms a large proportion of the asset ownership costs. Tsang [24] assessed the strategic vulnerability of outsourcing maintenance in terms of the supplier's strength, its depth in the supplier market, and the company's internal capabilities to assess or monitor suppliers.

The consideration of competitiveness is well-documented in supply chain management. Lonsdale [27] stressed the importance of not outsourcing competitive supply chain activities. He emphasised that, for an activity to be of value, it must contribute to a company's ability to provide superior services or products, be limited in supply, be difficult for competitors to imitate or substitute, be cost-effective to obtain or sustain, and fall within the boundaries of the organisation. Dunn [26] assessed competitiveness of maintenance for outsourcing by determining how competitive the function considered for outsourcing is currently being performed compared to the external competitive market. Tsang [24] assessed competitiveness of maintenance for outsourcing by proposing that if maintenance services are performed cheaper, faster and at superior quality in-house then it should remain an internal function.

\subsection{Decision factors in maintenance outsourcing}

Numerous studies found decision factors that were first identified in related fields - such as information systems, manufacturing, and supply chain management - being applied to the decision to outsource maintenance. The context of these studies varied from maintenance outsourcing in the Iranian petrochemical industry [28] to maintenance outsourcing in the Swedish pulp and steel industry [11], and strategic maintenance management [13], [24].

These studies provided evidence of core capabilities theory, outsourcing for increased flexibility, utilisation of economic decision factors, outsourcing to access external capabilities, potential risk-sharing benefits, corporate structure and culture suitability, competitiveness of the internal function, and strategic outsourcing being applicable during maintenance outsourcing decision-making.

Decision factors reported as inhibiting outsourcing in related fields have also been proven to be applicable to maintenance outsourcing. The decision to outsource maintenance was found to be susceptible to concerns over the loss of intellectual property, the loss of knowledge or skills, dependence on supplier, negative impacts on internal staff (such as reduced morale and employee loyalty), internal resistance to outsourcing, and the loss of control [28], [11].

The relevance of economic decision factors has been reported extensively in the literature [29]. In research into outsourcing in logistics management, cost reduction was cited as the major objective of outsourcing, while noting that the total cost of ownership was only applicable when the activity to be outsourced was of low strategic importance. The use of cost reduction as a factor in the decision to outsource maintenance has been noted frequently. Söderberg and Bengtsson [11] and Nili, Shekarchizadeh, Shojaey, \& Dehbanpur [28] observed that hidden costs resulted in organisations considering in-house execution of maintenance rather than outsourcing.

Campbell [12] noted two aspects that were uniquely applicable to the nature of the outsourcing decision in maintenance:

- Does the activity suffer from intractable problems or lost opportunities that are difficult to fix?

- Is the basic structure of the activity well-defined?

These decision factors were proposed as the starting point before further considering the possibility of outsourcing. In the same research, Campbell [12] also reported that a combination of service, quality, and cost should be used to compare internal execution with outsourcing.

Assaf, Hassanain, Al-Hammad and Al-Nehmi [30] performed a survey to establish which critical factors influenced the outsourcing decision for maintenance services at a number of Saudi Arabian universities, and also ranked the factors in importance to the respondents. Thirty-eight factors, grouped into six major groups, were included in the questionnaire. The authors found that the three most important factors that influenced the outsourcing decision at the universities were:

- $\quad$ increased speed of implementation

- $\quad$ improved quality requirements

- $\quad$ risk sharing with contractors 
Shrestha, Shrestha, Said \&, Lidder [31] conducted a survey with engineers of the Department of Transport (DOT) in the USA to determine which factors were relevant in the selection of maintenance and contracting methods in outsourcing road maintenance. The survey determined that the top two factors that influenced the decision to outsource and the contracting method were 1) the availability of departmental staff and 2) the specific skills of the departmental staff.

Ngoma [32] investigated the outsourcing of maintenance services at the Tshwane University of Technology. The objective of the research was to establish the current state of outsourcing at the university and to identify the most important factors that influence the decision to outsource the maintenance services. The factors that were identified were grouped under five categories: strategic, management, technological, economic, and quality.

Nili et al. [28] determined the risks and benefits associated with outsourcing maintenance services in the oil industry of Iran. These risks and benefits were viewed as factors that could influence the outsourcing decision. The factors were grouped under five categories: strategic, economical, technological, management, and quality. A survey of 182 managers in the oil and gas industry found that strategic factors were the most important in the outsourcing decision. The most important factors identified were "dependence on service provider" and "freeing resources for core activities".

Jafarnedad, Sherafat \& Talab [33] determined the variables and factors involved in the outsourcing decision by obtaining expert opinion. Three main factors were identified for maintenance outsourcing: the characteristics of the enterprise, of the environment or industry, and of the contractors. These factors were incorporated into a model for the outsourcing process that was tested in the electricity industry.

\subsection{Decision factors related to outsourcing in South African industries}

Some research into the relevance of outsourcing decision factors for maintenance outsourcing in South Africa has been published. The energy and mining sectors represent a major part of the manufacturing industry in South Africa.

Visser and Van Niekerk [34] investigated the role of relationship management in the success of maintenance outsourcing at production facilities. The following attributes or factors were identified as important to facilitatING successful outsourced maintenance:

- Sustainability of good performance

- More value created for both parties

- Sustainability of the service

- $\quad$ Better continuous improvement

- Win-win long-term partnership

- $\quad$ Supportive business case

- Good contract

Visagie [35], in research limited to the South African mining industry, noted cost reduction, increase in labour productivity, focus on core activities, access to specialised skills, improvement in equipment uptime and performance, improved quality, and reduced risk as popular motivating factors for outsourcing. In addition to these factors, he noted reduction in management effort, increased access to specialised equipment, and reduction in the influence of trade unions on internal operations as factors motivating outsourcing.

\section{CONCEPTUAL FRAMEWORK}

From the literature study discussed in the previous section, a total of 68 factors that might influence the outsourcing decision were identified [1], [11], [13], [17], [19], [23], [24], [25], [28], [29], [32], and [34], . The definitions or descriptions of some of these factors differed, and therefore some duplicates could be eliminated. A final list of 46 decision factors were selected for this research study.

The literature sources also indicated that decision factors could be grouped into a number of higher-level categories. The eight decision categories given below were selected for this grouping of decision factors, along with the number of decision factors in each category. 
Management (7) - considers the impact on the management of maintenance should outsourcing be accepted or rejected.

Strategic (7) - incorporates elements of strategic decision-making such as risk management, strategic alliances, and strategic direction of an organisation.

Economic (6) - factors that impact financial management in an organisation, such as cost reduction, budgeting, and operational expenditure.

Quality (4) - considers the quality of service to be obtained if outsourcing is adopted or rejected.

Environment (11) - factors that consider the business environment in which the organisation operates, the characteristics of the vendor, and the market to outsource maintenance.

Organisational characteristics (4) - factors related to the internal structure and characteristics of the outsourcing organisation.

Characteristics of the maintenance activity (4) - considers the nature of the maintenance activity to be outsourced in terms of complexity, relative performance of the staff executing the activity, and required assets.

Personnel impact (3) - factors that address the impact on internal staff when making the decision to adopt or reject maintenance outsourcing for a given activity.

The conceptual framework for management to make a decision to outsource or not to outsource certain parts of the maintenance function in an organisation is illustrated in Figure 1.

\begin{tabular}{|c|c|c|c|c|c|}
\hline $\begin{array}{l}\text { Select decision } \\
\text { factors to } \\
\text { consider }\end{array}$ & $\begin{array}{l}\text { Rank factors } \\
\text { in importance }\end{array}$ & $\begin{array}{c}\text { Select subset } \\
\text { of factors }\end{array}$ & $\begin{array}{l}\text { Define scoring } \\
\text { method for } \\
\text { specific case }\end{array}$ & $\begin{array}{l}\text { Calculate } \\
\text { overall score } \\
\text { for case }\end{array}$ & $\begin{array}{l}\text { Final decision } \\
\text { to outsource } \\
\text { or not }\end{array}$ \\
\hline
\end{tabular}

Figure 1: Conceptual framework for outsourcing decision process

This research study addressed the first two steps of the process outlined in Figure 1 - i.e., first, to define a large number of plausible decision factors that are proposed in the literature; and second, to rank these factors in terms of their importance for making the outsourcing decision. Each organisation might wish to define its own criteria for scoring the decision factors for a specific case or part of the maintenance function that has been identified as a possible candidate for outsourcing. A weighted approach is mostly used to calculate an overall score that can be used by management as one input in making the final decision about whether or not to outsource. The complete list of 46 decision factors with their definitions is provided as part of a Master's research project report [36].

\section{METHODOLOGY}

Primary quantitative data was obtained by means of a survey of engineering managers, maintenance managers, operations managers, contract managers, engineers, maintenance foremen, and maintenance technicians. Engineers and managers from companies contracted to perform outsourced activities also qualified as potential respondents to the survey. The population of interest was all individuals involved in decision-making about outsourcing maintenance in South African industrial organisations.

Organisations that qualified to participate in this survey were required to be in the aviation and aerospace, automotive, chemicals, consumer electronics, defence, food and beverage, mining and metals, oil and energy, paper and forest products, pharmaceuticals, telecommunications, transport and logistics, or utilities sectors. Another prerequisite for participation in the survey was that an organisation have a substantial number of physical assets and the associated maintenance workload.

Respondents were requested to indicate on a five-point scale the importance or applicability of a decision factor for making the outsourcing decision. The questionnaire was distributed by e-mail to 142 individuals in industrial organisations; 62 responses were received, resulting in a response rate of 44 per cent. Some questionnaires were distributed personally. Face-to-face distribution provides a higher response rate at the expense of additional time and cost. The questionnaire was pilot tested on a subset of five respondents prior to being distributed electronically via email and via face-to-face interaction. 
Respondents had to choose one of five options for the applicability of each of the 46 decision factors for making the outsourcing decision. These options were:

- $\quad$ Never (1)

- $\quad$ Rarely (2)

- $\quad$ Sometimes (3)

- $\quad$ Often (4)

- $\quad$ Always (5)

Three categories of data were captured using the questionnaire: the demographic data of the participants, individual opinions about the applicability of the 46 decision factors, and data on participants' previous involvement in the maintenance outsourcing decision.

The mean score and standard deviation of all 62 responses for each of the 46 decision factors was determined from the raw data, and ranked from highest to lowest to identify the most applicable or important factors to consider for the outsourcing decision. The mean values for the eight decision categories were also calculated and ranked to determine the most important category for the outsourcing decision.

The results for two industry sectors - i.e., 1) chemicals and 2) oil and energy - were compared. The other sectors were excluded from comparison due to insufficient responses being received. The results for two job roles - i.e., 1) management and 2) engineer were also compared. The mean values for each sector or job role were used for comparison.

5

\section{RESULTS}

The results obtained from the analysis of the data extracted from the questionnaires are discussed below.

\subsection{Demographics}

Some 46 of the respondents were from the oil and energy industry, while nine were from the chemical industry. Some 37 respondents were engineers, and 12 were engineering or maintenance managers.

\subsection{Importance of decision factor categories}

The mean values for each of the eight decision categories were calculated for all the respondents, as shown in Figure 2.

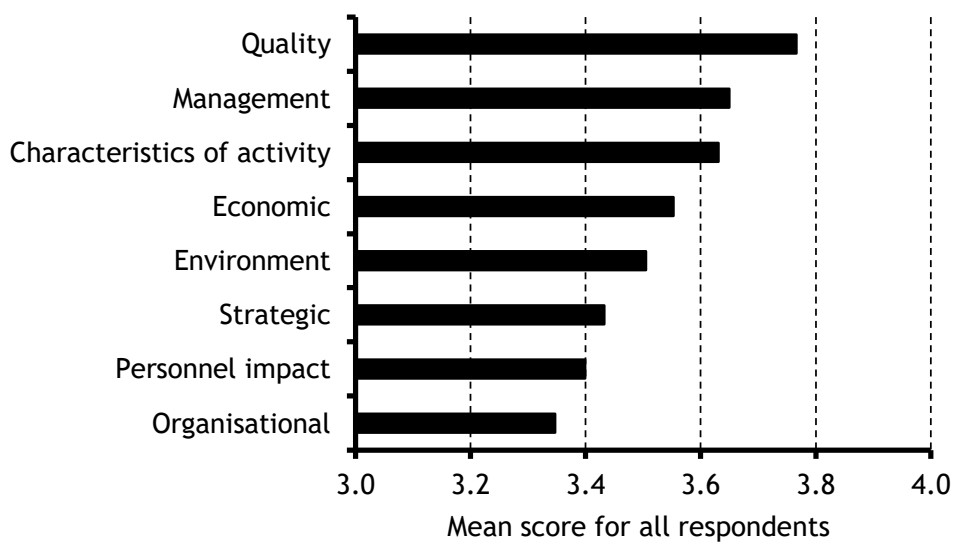

Figure 2: Mean scores per decision category

All the decision factor categories defined in the conceptual model were rated as important to the decision to outsource maintenance in the Southern African context, since the mean values of all responses was greater than 3.3 for all categories. 
The decision factors related to quality, management, and the characteristics of the maintenance activity were found to be the most applicable decision categories. These categories also showed the smallest standard deviation values. The organisational categories were considered the least applicable. In general, maintenance departments value the quality of maintenance and repair work very highly, since poor quality work often has safety consequences. The respondents revealed this attitude in their responses.

\subsection{Applicability of factors to the decision to outsource maintenance}

All 46 decision factors in the questionnaire were rated by the respondents. The ten decision factors that were rated as most applicable to the decision to outsource maintenance, and the five factors rated least applicable, are shown in Figure 3.

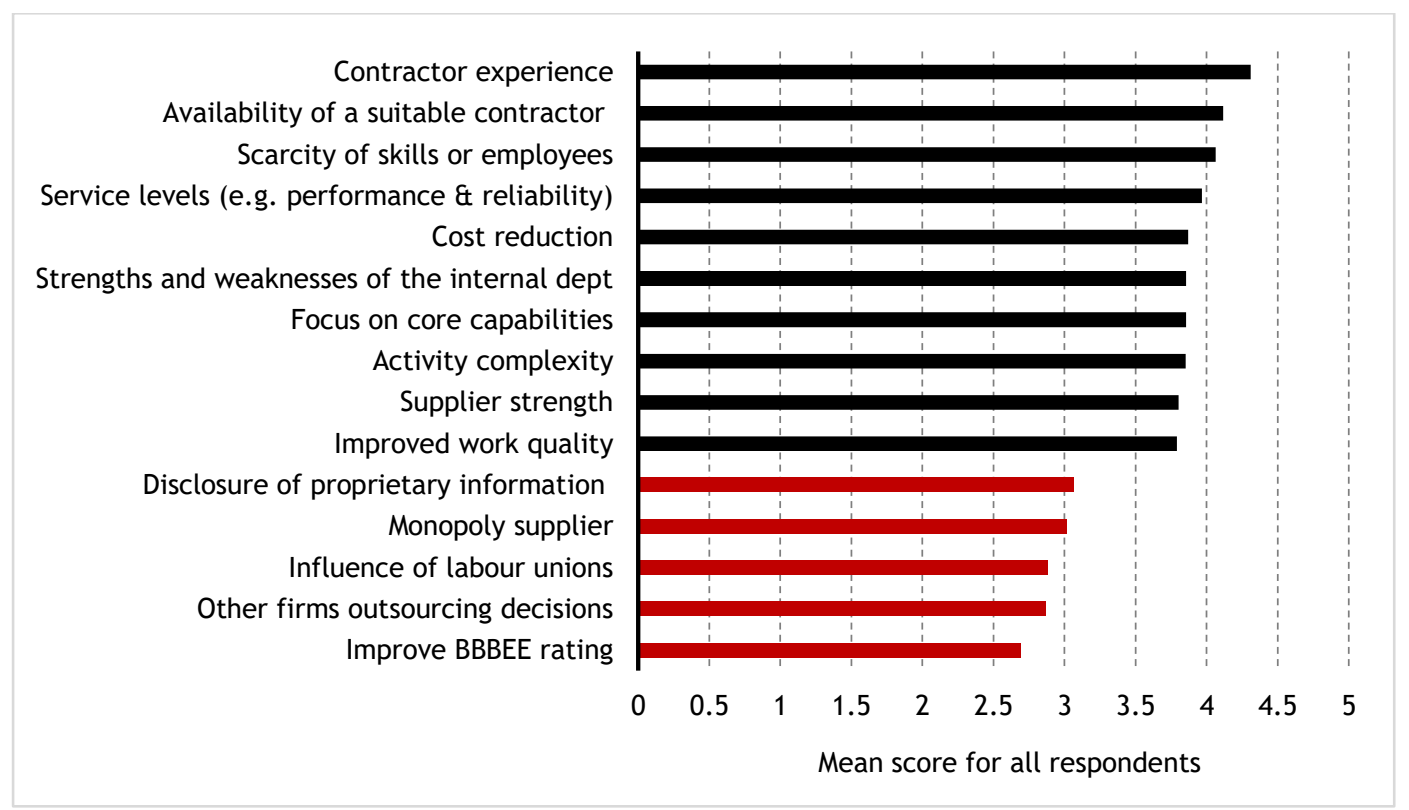

Figure 3: Mean response for top ten and bottom five decision factors

The resultant ranking of the individual decision factors mirrored the trends indicated in the comparison of the decision factor categories in the previous section, with the management and quality factors being among the top-ranking decision factors. However, the environmental category, found to be among the least prevalent categories, provided the two highest-ranked decision factors of 'contractor experience' and 'availability of a suitable contractor'. These results suggest that the decision to outsource maintenance was driven by factors inherent to the maintenance activities and the contractor's characteristics. Respondents did not consider 'improve BBBEE rating', 'labour unions' influence', and 'labour union resistance' as important factors to consider in the decision to outsource.

Responses varied the least in terms of factors external to the organisation, such as 'service levels in terms of performance and reliability', and 'contractor experience'. Variability in responses was greatest for the decision factors 'labour union resistance', 'reduce the influence of labour unions', and 'negative impact on internal staff'. This indicated that decision-makers were quite consistent in considering benchmarking and similar tools when considering the outsourcing of maintenance, but practices varied considerably for the factors that lack quantifiable measures.

\subsection{Previous outsourcing decisions}

The analysis revealed that 37.7 per cent of the respondents were not previously involved in the decision to outsource maintenance, while 42.6 per cent of the respondents indicated that their previous decisions resulted in maintenance being executed internally, and 19.7 per cent of the respondents indicated that their previous decisions resulted in maintenance being outsourced.

'Scarcity of skills or employees' was deemed to be the most import decision factor in previous maintenance outsourcing decision-making by a substantial margin. This was followed by 'cost reduction', 'formation of strategic alliance', and 'obtain improved work quality'. 
When the previous decisions resulted in the outsourcing of maintenance, 'scarcity of skills or employees', 'cost reduction', 'inability to justify full time staff', and 'strengths and weaknesses of the internal department' were reported as most important.

When the previous decisions resulted in maintenance being executed internally, 'scarcity of skills or employees', 'formation of strategic alliance', 'obtain improved work quality', and 'contractor experience' were reported as most important.

\subsection{Comparison of chemicals sector with oil and energy sector}

The highest-ranked decision factors for the chemicals and oil and energy sectors, in terms of applicability to the decision to outsource maintenance, are depicted in Figure 4 below.

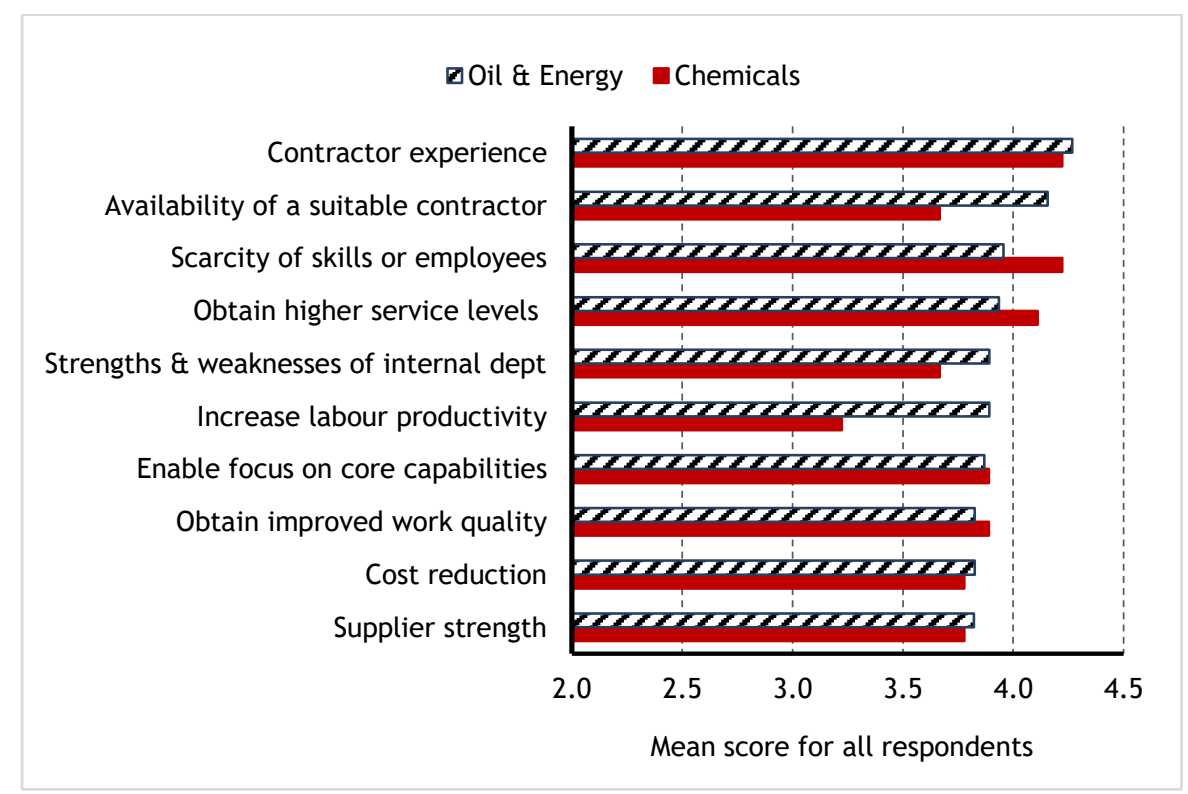

Figure 4: Mean response for 10 highest-rated decision factors for two sectors

The chemicals and the oil and energy sectors rated the decision factor categories in a similar manner, with the exception of the 'personnel impact' category, where a substantial difference was observed. The oil and energy sector rated this category as the least applicable, whereas the chemicals sector rated personnel impact decision factors as the third most applicable category.

In accordance with the disparity in the sectors' views of personnel impact factors, the comparison of the results per individual decision factor revealed that the chemicals sector was more cognisant of both the negative and the positive impacts of outsourcing on internal capabilities. The chemicals sector ranked 'reduction in the capabilities of internal staff' ( $16^{\text {th }}$ out of 46 factors) and 'transfer of knowledge to internal staff' ( $15^{\text {th }}$ out of 46 factors) as moderately applicable, whereas the oil and energy sector ranked these decision factors among the least applicable factors ( $38^{\text {th }}$ out of 46 factors).

These sectors also evaluated the outsourcer-supplier relationship in different ways. The chemicals sector considered 'risk of dependence on suppliers' to be more applicable to the decision to outsource than 'potential formation of strategic alliance'. An opposite view of the outsourcer-supplier relationship was observed in the oil and energy sector.

The factors most frequently reported by the oil and energy and the chemicals sectors as important during previous decision-making are depicted in Figure 5. 


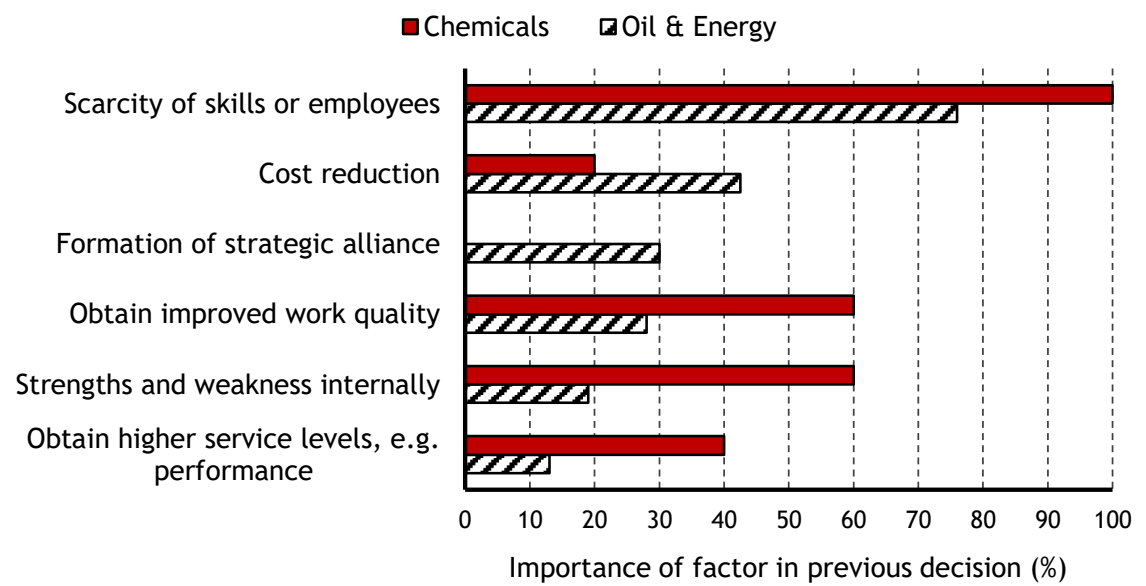

Figure 5: Importance of decision factors in previous outsourcing decisions per sector

The primary difference in the sectors' previous decision-making was the chemicals sector placing a priority on 'strengths and weaknesses of the internal department' and the possibility of 'obtaining higher service levels in terms of performance and reliability', whereas the oil and energy sector considered 'formation of strategic alliances' and possible 'cost reduction' as important decision factors. The low commodity prices in the oil and energy sector at the time of gathering the data may have resulted in this emphasis on cost reduction. Interestingly, 'scarcity of skills or employees' was reported as important in previous outsourcing decisions by all respondents in the chemicals sector.

\subsection{Management and engineering job role comparison}

The average scores for managers and engineers for the decision factor categories are quite similar, except for the 'characteristics of maintenance activity' category. Engineers ranked the characteristics of the maintenance activity category as the second most applicable decision factor category, whereas the same category was the fifth most applicable decision factor for managers. For all the decision factor categories, a greater variability in response was observed among managers than among engineers.

The highest-ranked decision factors for management and engineers for applicability to the decision to outsource maintenance are shown in Figure 6.

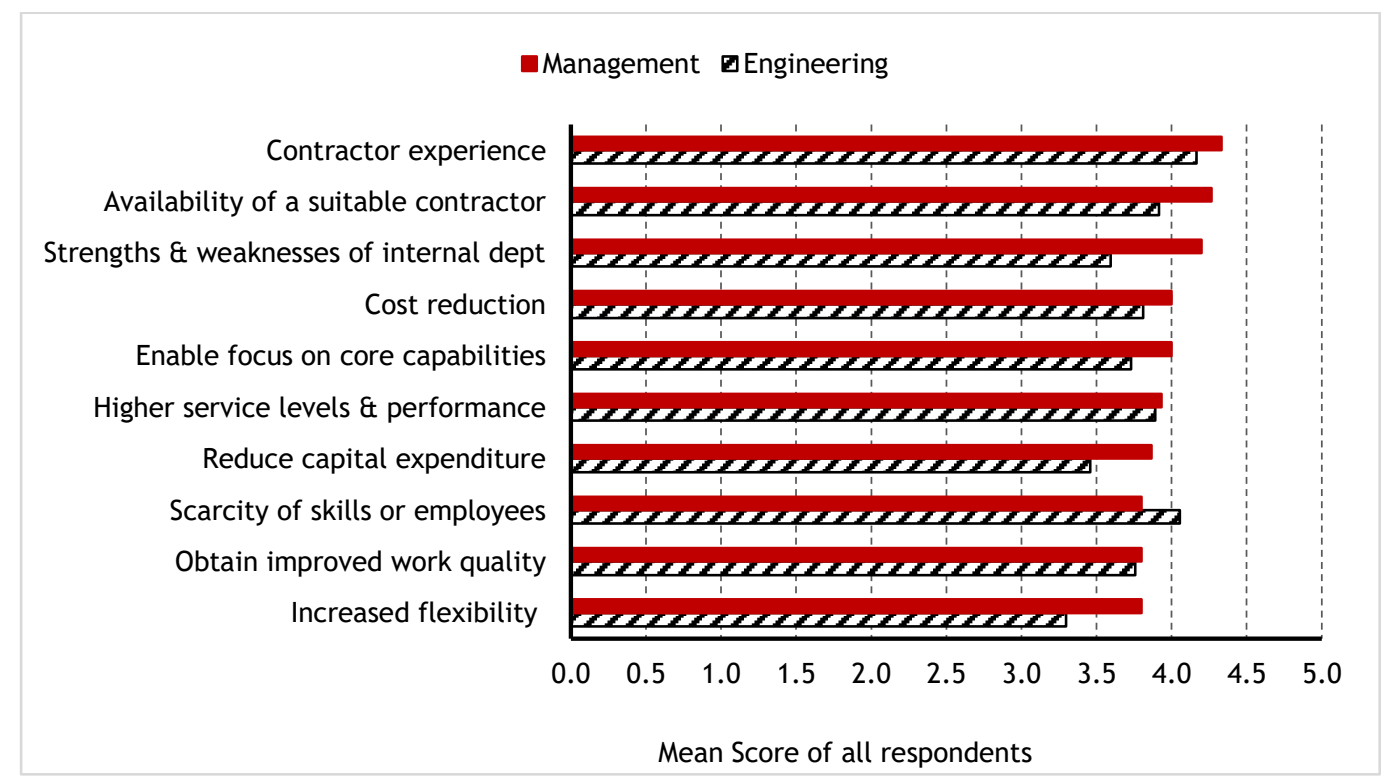

Figure 6: Mean response for highest-rated decision factors per job role 
The comparison of results per individual decision factor revealed that engineers and management differed somewhat in their perception of the applicability of 'cost to develop internal capabilities to match those of the supplier is not justifiable' and 'formation of strategic alliance'. Engineers considered these decision factors to be among the most applicable, whereas management considered these decision factors to be among the least applicable.

The factors most frequently reported by engineers and management as important during previous decisionmaking are depicted in Figure 7 below.

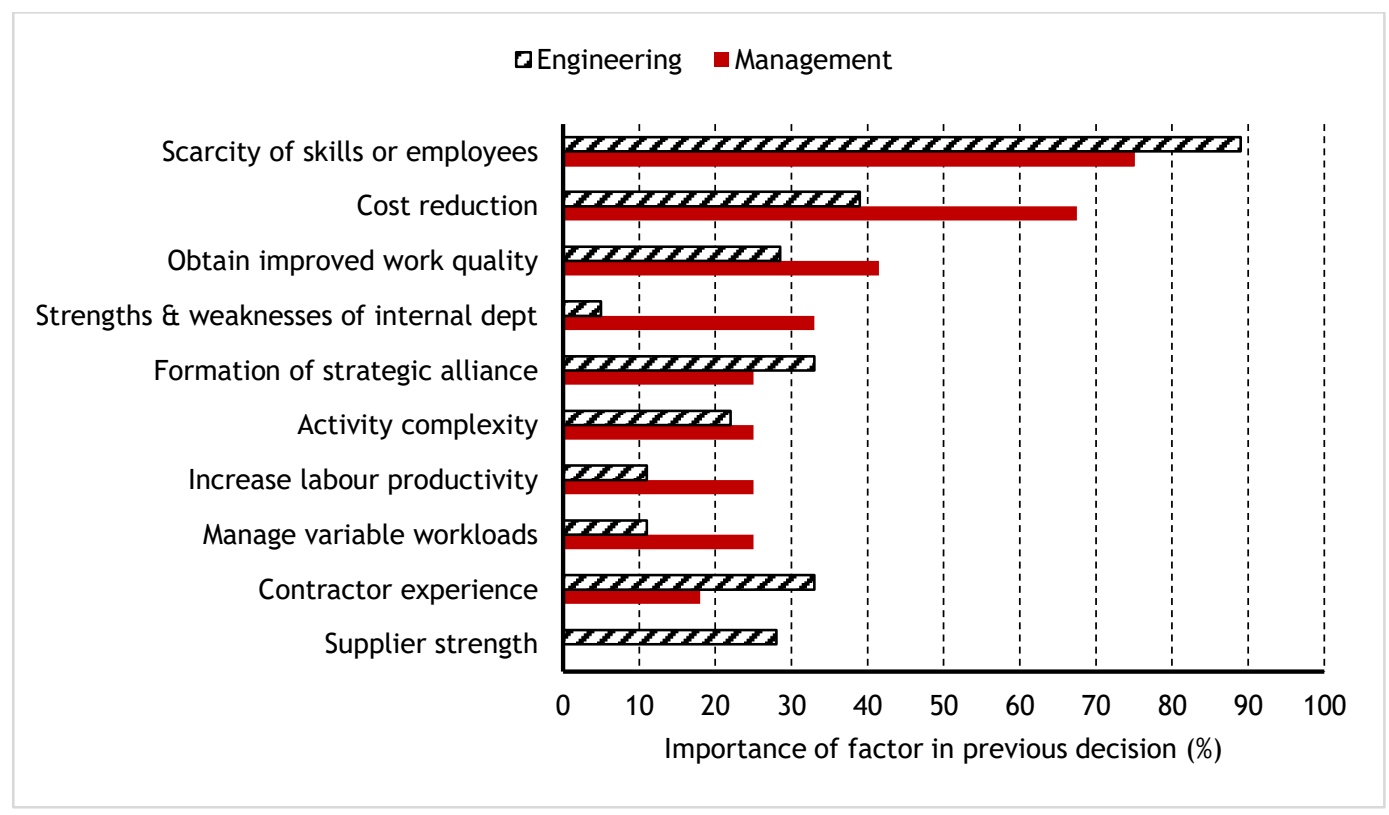

Figure 7: Importance of decision factors in previous outsourcing decisions

As indicated in Figure 7, engineers overwhelmingly viewed 'scarcity of skills or employees' as the most important factor in previous outsourced experiences, with 'cost reduction' as the second most important factor. The managers also viewed these two factors as the most important, with 'improved work quality' as the third most important. Interestingly, 'formation of strategic alliances', considered among the least applicable decision factors by management in the preceding section, was among management's most important decision factors in previous outsourcing decisions.

\section{CONCLUSIONS}

Data about the applicability of decision factors for outsourcing maintenance were obtained from various manufacturing organisations, mainly from the oil and energy and the chemical industries. The results indicated which of eight decision categories and 46 decision factors were deemed most applicable to the outsourcing decision. Small differences in the results were noted when the two main industries were compared, as well as when the responses from managers and engineers were compared.

It was found that organisations in the South African oil and energy industry consider decision factors related to the quality of service to be obtained, the impact on the management of maintenance activities, and the nature of the maintenance activity as most applicable to the maintenance outsourcing decision.

The ranking of decision factors found in this study is useful for engineering, maintenance, and asset managers to develop a scoring system, as shown in Figure 1. A subset of the 46 factors that were used in this study can be selected for the overall score. Relative weights can be assigned to the chosen factors according to the ranking. This overall score/value is one input into the final decision about whether or not to outsource to a specific contractor. A final decision would take into account other qualitative aspects or factors. 


\subsection{Factors applicable to the outsourcing decision for maintenance}

From the returns of the 62 respondents from some South African manufacturing industries, mainly oil and energy and chemical, the following five decision factors were found to be the most applicable and therefore important.

- Contractor experience

- $\quad$ Availability of a suitable contractor

- Scarcity of skills or employees

- Higher service levels

- Cost reduction

Maintenance and asset managers would benefit from carefully evaluating these factors whenever they contemplate the outsourcing of certain parts of the maintenance work. The experience of candidate contractors can be established from tender documents. A scoring system can also be designed to determine an overall score for a specific outsourcing situation.

\subsection{Factors when organisations encountered the maintenance outsourcing decision}

The factors considered most applicable to the decision to outsource by all participants were also found to be the most important when organisations were tasked with the decision to outsource maintenance. The following five decision factors were found to be the most applicable, and therefore important, when organisations last evaluated the outsourcing decision.

- Scarcity of skills or employees

- Cost reduction

- $\quad$ Formation of strategic alliances

- $\quad$ Obtain improved work quality

- $\quad$ Contractor experience

South African decision-makers considered outsourcing risks to be less important than the potential benefits of outsourcing, with 'loss of control' being the only risk-based factor reported as important in previous decisions about outsourcing.

\subsection{Comparison of chemicals industry and oil and energy industry}

The chemicals and oil and energy sectors mostly agreed on the top ten factors, with a small difference for 'availability of suitable contractor' and 'increase labour productivity'. Some larger differences were found for lower-ranked factors.

\subsection{Comparison of management and engineering job roles}

The managers and engineers who took part in the survey mostly agreed on the top ten decision factors, with a small difference for 'strengths and weaknesses of internal department' and 'increased flexibility'. Some larger differences were found for lower-ranked factors.

\section{REFERENCES}

[1] Ketler, K. \& Walstrom, J. 1993. The outsourcing decision. International Journal of Information Management, 13(6), pp. 449-459.

[2] Harland, C., Knight, L., Lamming, R. \& Walker, H. 2005. Outsourcing: Assessing the risks and benefits for organisations, sectors and nations. International Journal of Operations \& Production Management, 25(9), pp. 831850 .

[3] Ikediashi, D.I., Okwuashi, O. \& Warren, C.J. 2015. Significant factors influencing outsourcing decision for facilities management (FM) services: A study on Nigeria's public hospitals. Property Management, 33(1), pp. 5982.

[4] Gómez, J., Parra, C. Gonzalez, V., Moreu, P., Crespo, A. \& De Leon, P.M. 2009. Outsourcing maintenance in services providers. Safety, reliability and risk analysis: Theory, methods and applications. ESREL 2009 Conference Paper. (pp. 829-837). Taylor \& Francis Group, London.

[5] Welch, S. 2004. Advanced technology services: A plan for success. Available at: https://www.plantmaintenance.com/articles/OutsourcingPlan.pdf (Accessed on 1 February 2019.).

[6] Khumalo, F.M. 2010. Critical success factors for an outsourcing strategy in the Mpumalanga coal mining industry. MBA thesis, University of Pretoria.

[7] Gorla, N. \& Somers, T.M. 2014. The impact of IT outsourcing on information systems success. Information and Management, 51, pp. 320-335. 
[8] Delen, G.P.A.J., Peters, R.J., Verhoef, C. \& Van Vlijmen, S.F.M. 2016. Lessons from Dutch IT-outsourcing success and failure. Science of Computer Programming, 130, pp. 37-68.

[9] Iqbal, J., Ahmad, R.B., Khan, M., Fazal-e-Amin, Alyahya, S., Nasir, M.H.N.,Akhunzada, A, \& Shoaib, M. 2020. Requirements engineering issues causing software development outsourcing failure. PLoS ONE, 15(4), pp. 1-36.

[10] Global Forum on Maintenance and Asset Management (GFMAM). 2016. The maintenance framework. ISBN: 9780-9870602-5-9. Available at: https: //gfmam.org/publications (Accessed on 1 February 2019).

[11] Söderberg, L. \& Bengtsson, L. 2013. Outsourcing maintenance - Not always a good idea? The $20^{\text {th }}$ International Annual EurOMA conference, 9-12 June 2013, Dublin, Ireland.

[12] Campbell, J.D. 1995. Outsourcing in maintenance management: A valid alternative to self-provision. Journal of Quality in Maintenance Engineering, 1(3), pp. 18-24.

[13] Martin, H. 1997. Contracting out maintenance and a plan for future research. Journal of Quality in Maintenance Engineering, 3(2), pp. 81-90.

[14] Hall, R., Knights, P. \& Daneshmend, L. 2000. Pareto analysis and condition-based maintenance of underground mining equipment. Mining Technology, 109(1), pp. 14-22.

[15] Al-Turki, U. 2011. A framework for strategic planning in maintenance. Journal of Quality in Maintenance Engineering, 17(2), pp. 150-162.

[16] Campbell, J.D. \& Reyes-Picknell, J.V.. 2016. Uptime: Strategies for excellence in maintenance management, $3^{\text {rd }}$ Edition. CRC Press Boca Raton.

[17] Beaumont, N. \& Sohal, A. 2004. Outsourcing in Australia. International Journal of Operations \& Production Management, 24(7), pp. 688-700.

[18] Quinn, J.B. 1999. Strategic outsourcing: Leveraging knowledge capabilities. Sloan Management Review, 40(4), pp. 9-21.

[19] Yang, C. \& Huang, J.B. 2000. A decision model for IS outsourcing. International Journal of Information Management, 20(3), pp. 225-239.

[20] Steenkamp, C.J.H. \& Van der Lingen, E. 2014. Outsourcing in the mining industry: Decisionmaking framework and critical success factors. Journal of the Southern African Institute of Mining and Metallurgy, 114(10), pp. 845854.

[21] Geraerds, W. 1992. The EUT maintenance model. International Journal of Production Economics, 24(3), pp. 209216.

[22] Kong, C.N. 2005. Outsourcing total plant maintenance in Singapore petrochemical industry: A critical perspective. University of Southern Queensland. (Available at: https: //eprints.usq.edu.au/666/) (Accessed on 1 February 2019)

[23] Hattingh, T. \& Govender, R. 2014. To outsource or not to outsource: That is not the question. The $6^{\text {th }}$ International Platinum Conference. Southern African Institute of Mining and Metallurgy, North West Province, South Africa.

[24] Tsang, A.H. 2002. Strategic dimensions of maintenance management. Journal of Quality in Maintenance Engineering, 8(1), pp. 7-39.

[25] Venkatesan, R. 1992. Strategic sourcing: To make or not to make. Harvard Business Review, 70(6), pp. 98-107.

[26] Dunn, S. 1999. Maintenance outsourcing - critical issues. Available at: www.plant-maintenance. com/maintenance_articles_outsources.html [Online] (Accessed on 1 February 2019).

[27] Lonsdale, C. 1999. Effectively managing vertical supply relationships: A risk management model for outsourcing. Supply Chain Management: An International Journal, 4(4), pp. 176-183.

[28] Nili, M., Shekarchizadeh, A., Shojaey, R. \& Dehbanpur, M. 2013. Outsourcing maintenance activities or increasing risks? Case study in oil industry of Iran. International Journal of Academic Research in Business \& Social Sciences, 3(5), pp. 20-36.

[29] Ellram, L.M. \& Maltz, A.B. 1995. The use of total cost of ownership concepts to model the outsourcing decision. The International Journal of Logistics Management, 6(2), pp. 55-66.

[30] Assaf, S., Hassanain, M.A., Al-Hammad, A. \& Al-Nehmi, A. 2011. Factors affecting outsourcing decisions of maintenance services in Saudi Arabian universities. Property Management, 29 (2), pp. 195-212.

[31] Shrestha, P.P., Shrestha, K., Said, A. \& Lidder, M. 2017. Factors affecting the selection of in-house and outsourcing road maintenance methods and assessment of their benefits. Journal of Infrastructure Systems, 23(1):06016001

[32] Ngoma, D.M. 2017. Factors affecting outsourcing decisions of maintenance services at the Tshwane University of Technology. Master's dissertation, Tshwane University of Technology, South Africa.

[33] Jafarnedad, A., Sherafat, A. \& Talab, Z.A. 2013. Designing an operational evaluation model for outsourcing decision making by effective outsourcing factors. International Journal of Academic Research in Business and Social Sciences, 3(7), , pp. 371-383.

[34] Visser, J.K. \& Van Niekerk, A.J. 2010. The role of relationship management in the successful outsourcing of production critical maintenance. South African Journal of Industrial Engineering, 21(2), pp. 79-90.

[35] Visagie, C.J. 2005. Successful outsourcing of maintenance in the mining industry: Methods and principles. Master's dissertation, University of Johannesburg.

[36] Summers, D. 2017. Factors influencing the decision to outsource maintenance in South Africa. Master's research report, University of Pretoria. 